\title{
Unified Source Rock- A New Concept in Petroleum Exploration
}

\author{
Swapan Kumar Bhattacharya \\ K.D.M Chair Professor of Petroleum Geology, Dibrugarh University, Assam-786004, India.
}

\begin{abstract}
All Concepts of source rock are based on biogenic theory of petroleum generation but it is not decided which organic matter is responsible for petroleum generation. Therefore all the source rock (marine, lacustrine \& terrestrial) concepts consider all organic matters to be responsible for petroleum generation. Since 1926 AAPG together with USGS tried to find out source rock character by research but the attempt was not successful because technology was not developed. In the present work attempt is made to solve the problem related to which organic matter is responsible for petroleum generation and it has been established that only Lower Paleozoic marine organic matters were capable to generate petroleum. Based on this a unified source rock theory is proposed here suggesting there is only one episode of source rock deposition during Lower Paleozoic in our earth.
\end{abstract}

\section{Introduction}

In 1926 the concept of marine source rock for petroleum generation was accepted and AAPG immediately tried through research to characterize source rock for petroleum generation but research could not establish any characteristic for source rocks because technology was not well developed during that period. Because of this failure scientists of different period utilized their opinions to explain varieties of source rocks for petroleum generation even without proper scientific justification. Thus in 1968 Hedberg could introduce the concept of terrestrial source rock for high wax petroleum generation justifying wax is not generated in marine condition but he has not considered petroleum wax is different than bee-wax. Bee-wax are esters which definitely cannot be produced in marine environment but petroleum wax are paraffin which can be produced in marine condition and sometimes even reservoir alteration can also generate some wax. Attempt is made in this work to finalize the source character so that no further misconception can be introduced for identification of true source rock in a basin.

\section{Methodology}

To evaluate the source character first attempt is made to characterize organic matters for petroleum generation. For this purpose chemical composition of organic matters are compared to petroleum. Once the nature of organic matter is identified then the environment of deposition is verified. There after the global distribution of petroleum is compared as evidence to confirm source rock distribution.

\section{Results}

It is known that organic matters are composed of carbohydrates, lipids, lignins \& proteins of which carbohydrates remain in general higher percentage than the others and lignin remain only in terrestrial plants. Amongst all the compositions shown in Table-1 (Hunt,1995) average molar hydrogen relative to carbon is high only in lipids (1.89) which is even higher than petroleum(1.85). Carbohydrates have average hydrogen percentage of 1.64. However average lipid in a body does not exceed more than $20 \%$ in normal conditions suggesting organic matter is not suitable for petroleum generation. But evidences as well as results of biogenic theory cannot be denied to accept abiogenic theory. It is therefore necessary to find conditions whereby lipid percentage of organic matter can go high so that available hydrogen concentration relative to carbon becomes sufficient for petroleum generation. Experimentally it has been shown that lipid percentage in a body increase in hostile environment (Kalpesh, 2012). Also it is shown that lipids in terrestrial plants are large molecular esters above $\mathrm{C} 23$ but marine algae can produce lipids only below c22. It is therefore chemically clear that marine algae have higher relative hydrogen bearing lipids compared to terrestrial plants suggesting marine algae is more favourable for petroleum generation. It is therefore decided that marine algal organic matters particularly grown in hostile environments are the only organic matters favourable for petroleum generation. All marine organic bodies are also not favourable and no terrestrial organic matter is suitable for petroleum generation. Also it is evident that hostile environment can favour generation of higher lipids but repetition of same environment will not always help higher generation because body construction also changes for protection of body in hostile environment. 


\section{Discussions}

It is known that the oldest source rock of the world is marine source that belongs to Lower Paleozoic period. Figure-1 shows the present day distribution of lower Paleozoic source rocks in the world. Results of Fig1 show that lower Paleozoic source is present in almost all the countries. This is mainly because most of the countries at present are located above lower Paleozoic oceans or very close to ocean boundaries. Also during Lower Paleozoic period continents were close to each other and sea-level rise inundated major parts of lands.

Oils derived from the Paleozoic source are categorically distinguished by its lighter carbon isotope composition whereas oils from younger reservoirs are in general heavier. It is known that Paleozoic algae are relatively light in isotope composition (Lo Duca and Pratt,2002) and lipids are in general depleted of heavier carbon isotope compared to monosaccharides(Van Dongen Bart E2002) suggesting it is possible that the isotopic variations may be due to different source of oils or may be mixing different compounds with same oil. For this purpose the following environment analysis is made to characterize the source rock.

Plots of $\delta^{13} \mathrm{C}_{\text {arom }}$ versus $\delta^{13} \mathrm{C}_{\text {sat }}$ are used for characterization of terrestrial versus marine environment of source rock for a specific oil. Figure-3 shows a plot of $\delta^{13} C_{\text {arom }}$ versus $\delta^{13} C_{\text {sat }}$ for 19 oils of which 5 oils are of younger reservoir. Results show all are generated from same environment. Z. Sofer(1984) also carried out same analysis for 339 oils and observed same environment.

Figure-2 shows recent deltaic oil fields of the world together with their locations in the globe during Lower Paleozoic Silurian period. Figure shows the fields at present are mostly located above the Silurian oceans. During Silurian there was (1) Panthalsic ocean (2) Iapitas ocean (3) Rheic and (4) Paleo Tethys oceans in the world. Also during this period many of the land mass remained flooded because of sea level increase. Figure shows 1,2,3,7,8,11,12,13,17,18 are lying over panthalsic ocean 9,14 and15 are lying on the border above the subduction marker and 4, 5, 6 and 10 are lying on the border of paleotethys. Only 16 appears to lie over land mass which has discovery of Hydrocarbons in this delta lying in south china sea which lies over panthalsic and paleo Tethys ocean. Therefore data suggests even the tertiary oils in current deltas are possibly generated from the Lower Paleozoic source.

Results of Fig-1,2,3 therefore confirms all oils are generated from source rock deposited in same environment during Lower Paleozoic of the world. Therefore Lower Paleozoic source rocks are probable source of all oils.

The justifications above shows almost all the petroleum oils of the world are possible to have generated from Lower Paleozoic source. Also it is evident that Antarctica could not produce any petroleum because Antarctica during that period was lying in the south pole and other gondwana continents kept it separated from Lower Paleozoic oceans and it still remain in the same place although other gondwana continents moved away to present locations. Thus Antarctica could not have access to any lower Paleozoic oceanic sediments for which no petroleum is generated in this continent.

Thus the occurrences and non-occurrences of petroleum together support generation of petroleum from lower Paleozoic marine source rocks. This is particularly because nature allowed them to develop high lipid organic matter due to hostile environment and allowance of high $\mathrm{CO} 2$ for better photosynthesis. Although the Lower Plaeozoic hostile environment because of glaciations have also repeated in other periods but very high lipids are not formed because organic matters have changed composition to bear with changing environment. Amount of $\mathrm{CO} 2$ in the atmosphere is also not increased because of growth of land plants.

Thus it is more acceptable that organic matters of Lower Paleozoic oceans are only susceptible for kerogen formation to form petroleum but some younger rocks if get enriched with reworked kerogen of Lower Paleozoic sediments then those younger rocks may also source some petroleum oil \& gas generation.

\section{Conclusions}

Based on the above evidences and results it is concluded that Lower Paleozoic marine organic matters are only petroleum source organism. Based on this Unified source rock theory is proposed here as "There is only one episode of God gifted petroleum source rock deposition in world during Lower Paleozoic period". If Lower Paleozoic source rock is present then this will only generate petroleum. If it is not present then it is to be confirmed the basin evolution history and provenance of sediments to confirm if Lower Paleozoic kerogen could be redistributed in these sediments or not.

\section{References}

[1]. HEDBERG, H.D, 1968, Significance of high wax oils with respect to the genesis of petroleum, AAPG Bulletin, V52, pp.736-750

[2]. HUNT, J.M. 1995 Petroleum geochemistry \& Geology (2nd edition), published by W.H.Freeman and Company, Newyork (pp.63\&64).

[3]. KALPESH K. SHARMA, HOLGER SCHUHMANN AND PEER M. SCHENK, 2012, High Lipid induction in microalgae for biodiesel production, Energies, v-5, pp.1532-1553.

[4]. LODUCA S.T. AND L. PRATT, 2002, Stable carbon isotope compositions of compression fossils from Paleozoic KonservatLagerstatten, Palaios 17:287-291 
[5]. OLUKAYODE J. SAMUEL, D. MARTIN JONES, AND CHRIS CORNFORD, 2007, Intra delta versus sub-delta sourcing of petroleum - a global review, search \& discovery article\#40243.

[6]. SOFER, Z, 1984, Stable isotope compositions of crude oils: Applications to source depositional environments and petroleum alteration, AAPG Bulletin, V68, pp31-49.

[7]. SWAPAN KR. BHATTACHARYA, 2012, Changing Concepts of Petroleum Source rock. Published by Lap-Lambert Academic Publishing, Germany (pp.85 \&87).

[8]. WWW.SCOTESE.COM, 2016, Middle Silurian map of earth

[9]. VAN DONGEN BART E, SCHOUTEN STEFAN, DAMSTE JAAP S., 2002, Carbon isotope variability in monosaccharides and lipids of aquatic algae \& terrestrial plants (abstract), journal of marine ecology progress series, v 232, pp.83-92.

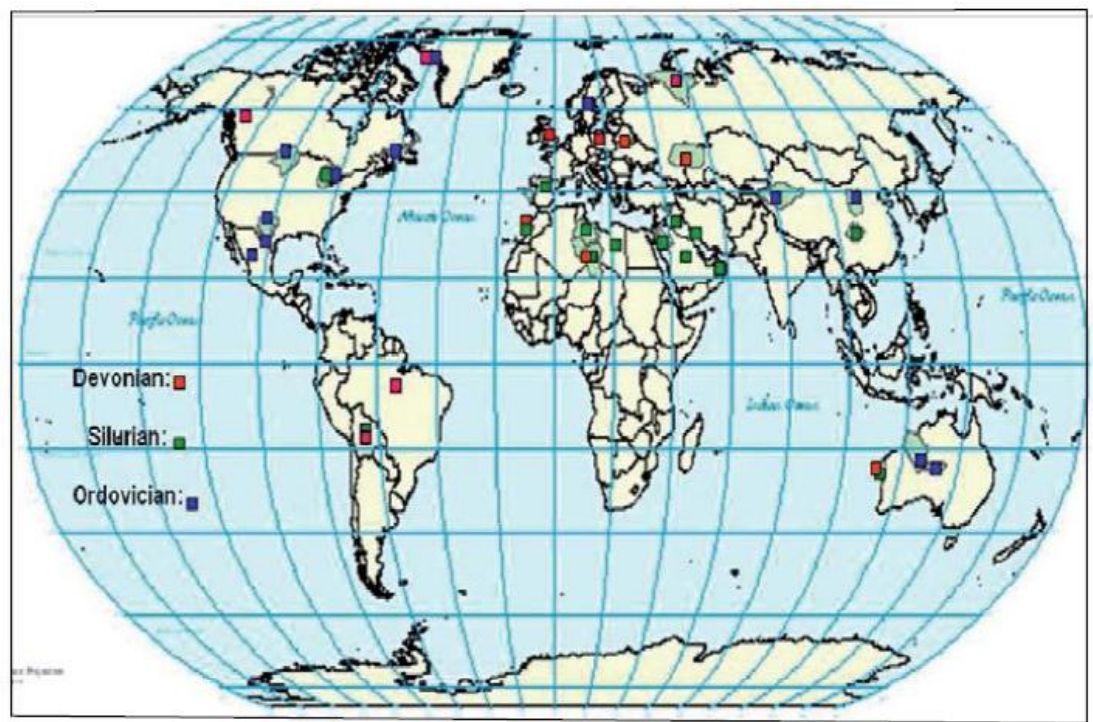

Swapan,2012

Mid.East: Arabian Gulf Basin (Saudi Arabia, Oman, Iraq, Iran, Jordon, Turkey); Africa: Illizi Basin(Algeria), Ghadames Basin(Algeria, Libiya, Tunisia), Essaouria Basin(Morocco); S.America: Santacruz - Tarija prov (Paraguay, Bolivia), Pernaiba Basin (Brazil); Portugal: Lusitanian Basin; Greenland: Franklinian Basin ; China: Tarim Basin, Ordos Basin; Australia: Canning, Amadeus, Gascoyne platform Basin; Russia: Timon-pechora, Lena-Tunguska; N.America: Michigan, Williston, Permian, Anadarko \& Arkoma basins; Canada: Anticosti, western Canada basins; Kazaksthan: Caspian sea basin; Belarus: Pripyat basin.

Figure-1: Lower Paleozoic source rock distribution in the world

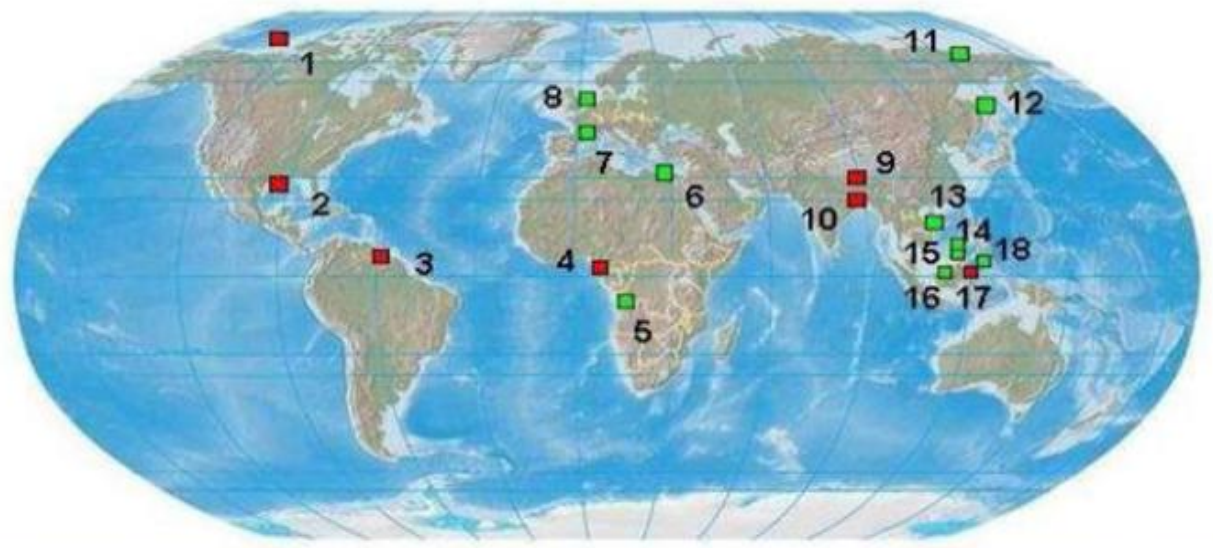

1= Beaufort-Mackenzie (Mackenzie). 2 = Gulf of Mexico (Mississippi). $3=$ Orinoco (Orinoco). $4=$ Niger (Niger-Benue). $5=$ Ogooué (Congo). $6=$ Nile (Nile). $7=$ Rhone (Rhone). 8 = Rhine (Rhine). $9=$ Assam (Ganges-Brahmaputra). $10=$ Ganges-Brahmaputra (GangesBrahmaputra) $\cdot 11=$ Lena (Lena) $\cdot 12=$ Amur- $($ Amur-Darya $) \cdot 13=$ Mekong (Mekong) $\cdot 14=$ Sabah (Sabah), $15=$ Baram (Baram). $16=$ Balingian (Balingian). $17=$ Mahakam (Mahakam). 18 = Tarakan (Tarakan).

Olukayode, 2007 


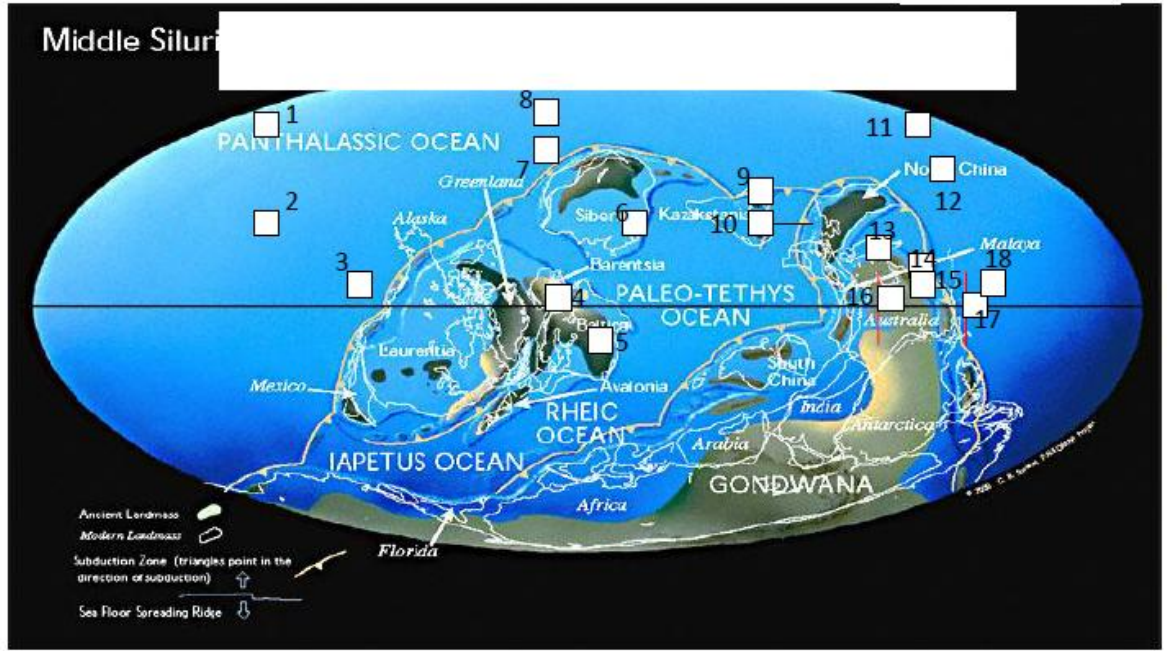

Figure 2: Map of the world showing the distribution of the major Tertiary deltaic basins with location during Lower Plaeozoic Period (www.scotese com)

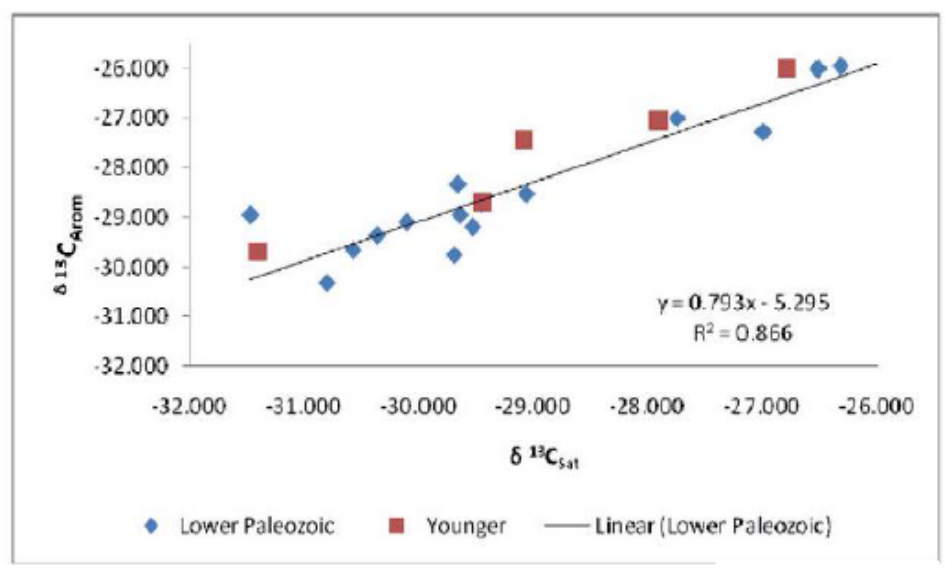

Swapan,2012

Fig.3: Plot showing uniform trend of source depositional environment for Lower Paleozoic \& Younger oils

\begin{tabular}{|c|c|c|c|c|c|c|}
\hline & $\mathrm{C}$ & $\mathrm{H}$ & $\mathrm{S}$ & $\mathrm{N}$ & $\mathrm{O}$ & $\mathrm{H} / \mathrm{C}^{*}$ \\
\hline Carbohydrate & 44 & 6 & & & 50 & 1.64 \\
\hline Protein & 53 & 7 & 1 & 17 & 22 & 1.58 \\
\hline Lipid & 76 & 12 & & & 12 & 1.89 \\
\hline Lignin & 63 & 5 & 0.1 & 0.3 & 31.6 & 0.95 \\
\hline Petroleum & 84.5 & 13 & 1.5 & 0.5 & 0.5 & 1.85 \\
\hline Coal & 81 & 5 & 3 & 1 & 10 & 0.74 \\
\hline
\end{tabular}

Table-1: Composition of organic matters, petroleum and coal $\mathrm{H} / \mathrm{C}^{* *}=$ Molar hydrogen to carbon ratio 